\title{
Pemeringkatan Pegawai Berprestasi Menggunakan Metode AHP (Analytic Hierarchy Process) di PT. XYZ
}

\author{
Andri Suryadi ${ }^{1}$, Erwin Harahap ${ }^{2}$ \\ ${ }^{1}$ Program Studi Pendidikan Teknologi Informasi, Institut Pendidikan Indonesia Garut, Garut. \\ ${ }^{2}$ Program Studi Matematika, FMIPA, Universitas Islam Bandung, Bandung.
}

suryadi.andri@yahoo.com, erwin2h@unisba.ac.id

\begin{abstract}
Abstrak. Untuk mendapatkan pegawai terbaik perlu adanya pemeringkatan berdasarkan kriteria yang telah ditetapkan oleh PT XYZ. Salah satu kriteria yang dimaksud adalah kemampuan hard-skills dan soft-skills. Namun, dengan adanya kategori tersebut menjadi sulit bagi pimpinan perusahaan untuk mendapatkan keputusan yang terbaik terutama dalam relasi antar kategori yaitu kolaborasi hard-skills dan soft-skills. Oleh karena itu dibutuhkan suatu metode untuk dapat memeringkatkan pegawai berprestasi sehingga dapat memudahkan pimpinan dalam pemilihan tersebut. Analytic Hierarchy Process (AHP) merupakan metode yang dapat menyelesaikan masalah pengambilan keputusan berdasarkan banyak kategori. Kemampuan hard-skills dan soft-skills dapat dikolaborasikan menggunakan AHP sehingga keterkaitan antara kategori menjadikan proses pemilihan pegawai berprestasi menjadi mudah.
\end{abstract}

Kata kunci: pegawai berprestasi, hard-skills, soft-skills, AHP, analytic hierarchy process.

\begin{abstract}
Ranking of High-Performance Employees Using the AHP (Analytic Hierarchy Process) Method at PT XYZ) To get the best employees need to rank based on the criteria set by PT XYZ. One of the criteria in question is the ability of hard-skills and soft-skills. However, with the category, it becomes difficult for the leadership of the company to get the best decision especially in the relationships between categories of collaboration hard-skills and soft-skills. Therefore, it is necessary a method to be able to improve employee achievement to facilitate the leadership in the election. Analytic Hierarchy Process (AHP) is a method that can solve the problem of decision making based on many categories. The ability of hard-skills and soft-skills can be collaborated using AHP so that the interrelationship between the categories makes the eligible employee selection process easy.
\end{abstract}

Keywords: employee achievement, hard-skills, soft-skills, AHP, analytic hierarchy process.

\section{Pendahuluan}

\subsection{Latar Belakang}

Dalam proses pemilihan pegawai berprestasi ada beberapa kategori kemampuan digunakan oleh PT XYZ untuk mendapatkan pegawai yang terbaik. Kategori kemampuan yang dimaksud adalah kemampuan hard-skills dan soft-skills. Hard-skills merupakan kemampuan yang lebih kepada ilmu pengetahuan perusahaan seperti kemampuan perusahaan dalam menjalani proses bisnis, ketepatan menyelesaikan tugas dan lain sebagainya. Sedangkan kemampuan soft-skills merupakan kemampuan lebih kearah kemampuan kehidupan sosial seperti komunikasi, kedisiplinan, kemauan dan lain sebagainya. Namun, dengan adanya kategori tersebut menjadi sulit bagi pimpinan perusahaan untuk mendapatkan keputusan yang terbaik terutama dalam relasi antar kategori yaitu kolaborasi hard-skills dan soft-skills. Oleh karena itu dibutuhkan suatu metode untuk dapat menyelesaikan pengambilan keputusan dengan banyak kategori.

Analytic Hierarchy Process (AHP) merupakan metode yang dapat menyelesaikan masalah pengambilan keputusan berdasarkan banyak kategori. Kemampuan hard-skills dan soft-skills dapat 
dikolaborasikan menggunakan AHP sehingga keterkaitan antara kategori menjadikan proses pemeringkatan menjadi optimal.

Dalam implementasi penelitian ini akan di lakukan terhadap pegawai-pegawai yang bekerja di PT XYZ sesuai dengan kriteria yang telah ditetapkan. Proses pemeringkatan berdasarkan dari kemampuan hard-skills dan soft-skills yang telah dipantau oleh pimpinan diwakili Human Resources Development (HRD) perusahaan. Dengan adanya proses pemeringkatan menggunakan metode AHP ini, diharapkan keputusan yang diambil oleh pimpinan menjadi lebih reliable.

\subsection{Rumusan Masalah}

Penelitian ini membahas bagaimana implementasi metode AHP dalam proses pemeringkatan pegawai berprestasi dengan multi kriteria sehingga dapat membuat sebuah rangking yang dapat menjadi rekomendasi pimpinan.

\subsection{Tujuan Penelitian}

Tujuan penelitian ini adalah sebagai berikut:

a. Mengetahui implementasi metode AHP dalam proses pemeringkatan pegawai berprestasi dengan multi kriteria.

b. Menyusun rangking pegawai berprestasi menggunakan metode AHP.

\subsection{Manfaat Penelitian}

Beberapa manfaat dari penelitian ini adalah:

a. Membuat kemudahan pimpinan dalam hal pemilihan pegawai berprestasi.

b. Keputusan pimpinan menjadi lebih akurat dalam hal pemilihan pegaw ai berprestasi

\section{Konsep Garis Kutub}

\subsection{Pengertian AHP}

AHP merupakan suatu model pendukung keputusan yang dikembangkan oleh Thomas L. Saaty. Model pendukung keputusan ini akan menguraikan masalah multi faktor atau multi kriteria yang kompleks menjadi suatu hirarki. Menurut Saaty (1993), hirarki didefinisikan sebagai suatu representasi dari sebuah permasalahan yang kompleks dalam suatu struktur multi-level dimana level pertama adalah tujuan, yang diikuti level faktor, kriteria, sub kriteria, dan seterusnya ke bawah hingga level terakhir dari alternatif. Dengan hirarki, suatu masalah yang kompleks dapat diuraikan ke dalam kelompok-kelompoknya yang kemudian diatur menjadi suatu bentuk hirarki sehingga permasalahan akan tampak lebih terstruktur dan sistematis.

AHP sering digunakan sebagai metode pemecahan masalah dibanding dengan metode yang lain karena alasan-alasan sebagai berikut :

1. Struktur yang berhirarki, sebagai konsekuensi dari kriteria yang dipilih, sampai pada subkriteria yang paling dalam.

2. Memperhitungkan validitas sampai dengan batas toleransi inkonsistensi berbagai kriteria dan alternatif yang dipilih oleh pengambil keputusan.

3. Memperhitungkan daya tahan output analisis sensitivitas pengambilan keputusan.

\subsection{Prinsip AHP}

Dalam menyelesaikan persoalan dengan metode AHP ada beberapa prinsip dasar yang harus dipahami antara lain : 


\section{a. Decomposition}

Pengertian decomposition adalah memecahkan atau membagi problema yang utuh menjadi unsur- unsurnya ke bentuk hirarki proses pengambilan keputusan, dimana setiap unsur atau elemen saling berhubungan. Untuk mendapatkan hasil yang akurat, pemecahan dilakukan terhadap unsur-unsur sampai tidak mungkin dilakukan pemecahan lebih lanjut, sehingga didapatkan beberapa tingkatan dari persoalan yang hendak dipecahkan. Struktur hirarki keputusan tersebut dapat dikategorikan sebagai complete dan incomplete. Suatu hirarki keputusan disebut complete jika semua elemen pada suatu tingkat memiliki hubungan terhadap semua elemen yang ada pada tingkat berikutnya, sementara hirarki keputusan incomplete kebalikan dari hirarki complete. Bentuk struktur dekomposisi, yakni :

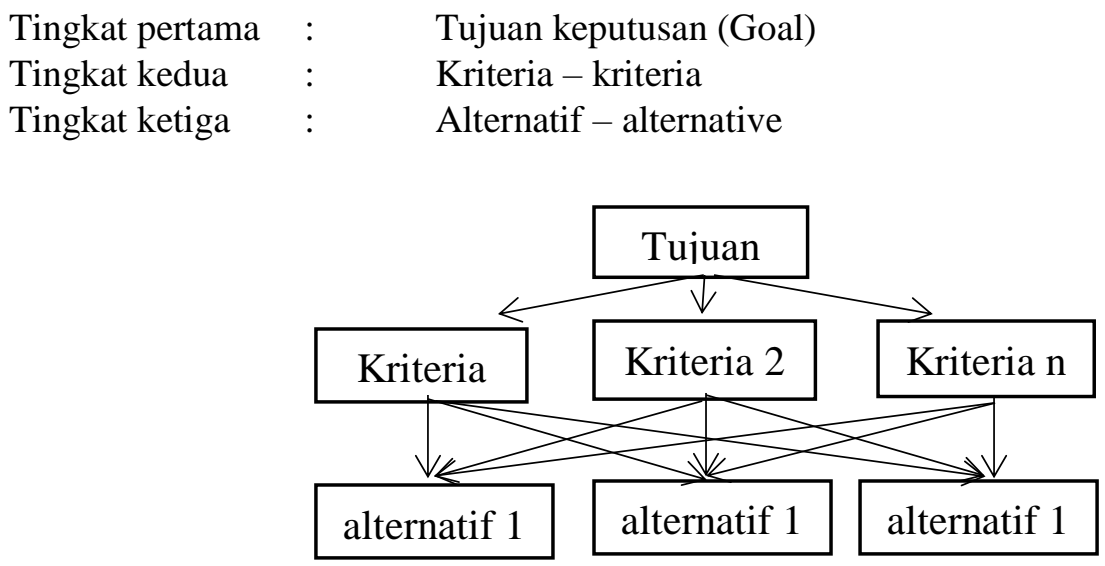

Gambar 2.1 Struktur Hirarki

\section{b. Comparative Judgement}

Comparative judgement dilakukan dengan penilaian tentang kepentingan relatif dua elemen pada suatu tingkat tertentu dalam kaitannya dengan tingkatan diatasnya. Penilaian ini merupakan inti dari AHP karena akan berpengaruh terhadap urutan prioritas dari elemen-elemennya. Hasil dari penilaian ini lebih mudah disajikan dalam bentuk matriks pairwise comparisons yaitu matriks perbandingan berpasangan memuat tingkat preferensi beberapa alternatif untuk tiap kriteria. Skala preferensi yang digunakan yaitu skala 1 yang menunjukkan tingkat yang paling rendah (equal importance) sampai dengan skala 9 yang menujukkan tingkatan paling tinggi (extreme importance).

\section{c. Synthesis of Priority}

Synthesis of priority dilakukan dengan menggunakan eigen vector method untuk mendapatkan bobot relatif bagi unsur-unsur pengambilan keputusan.

\section{d. Logical Consistency}

Logical consistency merupakan karakteristik penting AHP. Hal ini dicapai dengan mengagresikan seluruh eigen vector yang diperoleh dari berbagai tingkatan hirarki dan selanjutnya diperoleh suatu vektor composite tertimbang yang menghasilkan urutan pengambilan keputusan.

\subsection{Penyusunan Prioritas}

Setiap kriteria yang sudah ditentukan maka harus diketahui bobotnya. Hal ini bertujuan untuk mengetahui tingkat kepentingan terhadap kriteria yang ada. Langkah pertama adalah menyusun perbandingan berpasangan dengan cara membandingkan setiap kriteria yang ada. Misalkan terhadap sub sistem hirarki dengan kriteria $C$ dan sejumlah $n$ alternatif dibawahnya, sampai . Perbandingan antar alternatif untuk sub sistem hirarki itu dapat dibuat dalam bentuk matriks $n \times n$, seperti pada dibawah ini. 
Tabel 2.1 Tabel matriks berpasangan

\begin{tabular}{|c|c|c|c|c|}
\hline $\mathrm{C}$ & $\mathrm{A}_{1}$ & $\mathrm{~A}_{2}$ & $\mathrm{~A}_{3}$ & $\mathrm{~A}_{\mathrm{n}}$ \\
\hline $\mathrm{A}_{1}$ & $\mathrm{~A}_{11}$ & $\mathrm{~A}_{12}$ & $\mathrm{~A}_{13}$ & $\mathrm{~A}_{1 \mathrm{n}}$ \\
\hline $\mathrm{A}_{2}$ & $\mathrm{~A}_{21}$ & $\mathrm{~A}_{22}$ & $\mathrm{~A}_{23}$ & $\mathrm{~A}_{2 \mathrm{n}}$ \\
\hline $\mathrm{A}_{3}$ & $\mathrm{~A}_{31}$ & $\mathrm{~A}_{32}$ & $\mathrm{~A}_{33}$ & $\mathrm{~A}_{3 \mathrm{n}}$ \\
\hline $\mathrm{A}_{\mathrm{m}}$ & $\mathrm{A}_{\mathrm{m} 1}$ & $\mathrm{~A}_{\mathrm{m} 2}$ & $\mathrm{~A}_{\mathrm{m} 3}$ & $\mathrm{~A}_{\mathrm{mn}}$ \\
\hline
\end{tabular}

Nilai $A_{11}$ adalah nilai perbandingan elemen $A_{1}$ (baris) terhadap $A_{1}$ (kolom) yang menyatakan hubungan :

a. Seberapa jauh tingkat kepentingan $A_{1}$ (baris) terhadap kriteria $\mathrm{C}$ dibandingkan dengan $\mathrm{A}_{1}$ (kolom) atau

b. Seberapa jauh dominasi $A_{1}$ (baris) terhadap $A_{1}$ (kolom) atau

c. Seberapa banyak sifat kriteria $C$ terdapat pada $A_{1}$ (baris) dibandingkan dengan $A_{1}(k o l o m)$.

Nilai numerik yang dikenakan untuk seluruh perbandingan diperoleh dari skala perbandingan 1 sampai 9 yang telah ditetapkan oleh Saaty, seperti pada tabel berikut ini :

1 = Kedua elemen sama pentingnya, Dua elemen mempunyai pengaruh yang sama besar

3 = Elemen yang satu sedikit lebih penting daripada elemen yang lainnya, Pengalaman dan penilaian sedikit menyokong satu elemen dibandingkan elemen yang lainnya

5 = Elemen yang satu lebih penting daripada yang lainnya, Pengalaman dan penilaian sangat kuat menyokong satu elemen dibandingkan elemen yang lainnya.

7 = Satu elemen jelas lebih mutlak penting daripada elemen lainnya, Satu elemen yang kuat disokong dan dominan terlihat dalam praktek.

9 = Satu elemen mutlak penting daripada elemen lainnya, bukti yang mendukung elemen satu terhadap elemen lain memiliki tingkat penegasan tertinggi yang mungkin menguatkan.

2,4,6,8 = Nilai-nilai antara dua nilai pertimbangan-pertimbangan yang berdekatan, Nilai ini diberikan bila ada dua kompromi di antara 2 pilihan

Kebalikan $=$ Jika untuk aktivitas $i$ mendapat satu angka dibanding dengan aktivitas $j$, maka $j$ mempunyai nilai kebalikannya dibanding dengan $i$.

\subsection{Eigen Value dan Eigen Vektor}

Jika $A$ adalah matriks $n \times \mathrm{x} n$ maka vector tak nol $x$ di dalam $R^{n}$ dinamakan Eigen Vector dari $A$ jika $A x$ kelipatan skalar $\lambda$, yakni:

$$
A x=\lambda x
$$

Skalar $\lambda$ dinamakan eigen value dari $A$ dan $x$ dikatakan eigen vektor yang bersesuaian dengan $\lambda$. Untuk mencari eigen value dari matriks $A$ yang berukuran $n \times n$ maka dapat ditulis pada persamaan berikut :

$$
A x=\lambda x
$$

atau secara ekivalen

$$
(\lambda \mathrm{I}-A) x=0
$$

Agar $\lambda$ menjadi eigen value, maka harus ada pemecahan tak nol dari persamaan ini. Akan tetapi, persamaan diatas akan mempunyai pemecahan tak nol jika dan hanya jika : 


$$
\operatorname{det}(\lambda \mathrm{I}-A) x=0
$$

Ini dinamakan persamaan karakteristik $A$, skalar yang memenuhi persamaan ini adalah eigen value dari A.

\subsection{Uji Konsistensi Indeks Rasio}

Pengukuran konsistensi dari suatu matriks itu sendiri didasarkan atas eigen value maksimum. Thomas L. Saaty telah membuktikan bahwa indeks konsistensi dari matriks ber-ordo $n$ dapat diperoleh dengan rumus sebagai berikut :

$$
\mathbf{C I}=(\boldsymbol{\lambda} \text { maks }-\boldsymbol{n}) /(\boldsymbol{n}-\mathbf{1})
$$

$\mathrm{CI}=$ Rasio Penyimpangan (deviasi) konsistensi (consistency indeks)

$\lambda$ maks $=$ Nilai eigen terbesar dari matriks ber-ordo $n$

$n \quad=$ Orde matriks

Apabila CI bernilai nol, maka matriks pair wise comparison tersebut konsisten. Batas ketidakkonsistenan (inconsistency) yang telah ditetapkan oleh Thomas L. Saaty ditentukan dengan menggunakan Rasio Konsistensi (CR), yaitu perbandingan indeks konsistensi dengan nilai Random Indeks (RI) yang didapatkan dari suatu eksperimen oleh Oak Ridge National Laboratory kemudian dikembangkan oleh Wharton School dan diperlihatkan seperti tabel 2.2. Nilai ini bergantung pada ordo matriks $n$. Dengan demikian, Rasio Konsistensi dapat dirumuskan sebagai berikut :

$$
\mathbf{C R}=\mathbf{C I} / \mathbf{R I}
$$

$$
\begin{aligned}
& \mathrm{CR}=\text { Rasio Konsistensi } \\
& \mathrm{RI}=\text { Indeks Random }
\end{aligned}
$$

Tabel 2.2 Tabel Random Konsistensi

\begin{tabular}{|c|c|c|c|c|c|c|c|c|}
\hline $\boldsymbol{n}$ & $\mathbf{1}$ & $\mathbf{2}$ & $\mathbf{3}$ & $\mathbf{4}$ & $\mathbf{5}$ & $\mathbf{6}$ & $\mathbf{7}$ & $\mathbf{8}$ \\
\hline $\mathbf{R I}$ & 0,00 & 0,00 & 0,58 & 0,90 & 1,12 & 1,24 & 1,32 & 1,41 \\
\hline
\end{tabular}

\begin{tabular}{|c|c|c|c|c|c|c|c|}
\hline $\boldsymbol{n}$ & $\mathbf{9}$ & $\mathbf{1 0}$ & $\mathbf{1 1}$ & $\mathbf{1 2}$ & $\mathbf{1 3}$ & $\mathbf{1 4}$ & $\mathbf{1 5}$ \\
\hline $\mathbf{R I}$ & 1,45 & 1,49 & 1,51 & 1,48 & 1,56 & 1,57 & 1,59 \\
\hline
\end{tabular}

Bila matriks pair-wise comparison dengan nilai CR lebih kecil dari 0,100 maka ketidakkonsistenan pendapat dari decision maker masih dapat diterima jika tidak maka penilaian perlu diulang.

\section{Hasil Penelitian}

\subsection{Menentukan Jenis Kriteria}

Tahapan pertama dalam penelitian ini adalah menentukan jenis kriteria yang akan dijadikan dasar dalam proses pemeringkatan prestasi pegawai. Kriteria ini diambil oleh tim HRD perusahaan berdasarkan kemampuan hard-skills dan soft-skills. Hard-skills yang akan diujikan berupa ilmu pengetahuan tentang perusahaan. Hard-skills ini akan diujikan melalui tes tertulis yang nantinya akan didapatkan angka setiap orangnya. Dalam pengujian kemampuan hard-skills ini diharapkan dapat mengetahui kemampuan mengenai bagaimana perusahaan berjalan.

Sedangkan soft-skills yang akan diujikan berupa motivasi (visi) kedepan, disiplin dan komunikasi. Soft-skills diujikan melalui tes wawancara oleh bagian HRD kepada setiap pegawai. Motivasi 
merupakan salah satu kriteria pertama yang diujikan karena pegawai harus mempunyai motivasi/visi yang tinggi selain kemampuannya. Kemudian kriteria selanjutnya adalah disiplin, disiplin dalam hal ini adalah disiplin dalam bertanggung jawab, tegar dalam menghadapi segala situasi, lebih menghargai orang lain dan waktu, tidak mudah putus asa dan melatih kejujuran. Kemudian kriteria terakhir adalah komunikasi. Seorang calon pegawai berprestasi harus dapat berkomunikasi dengan baik kepada sesama rekan kerja maupun kepada atasan.

\subsection{Struktur Hirarki}

Dari beberapa kriteria yang telah ditentukan sebelumnya maka dapat dibuat struktur hirarki sebagai dasar penentuan pengambilan keputusan menggunakan AHP. Struktur hirarki yang dapat dibuat adalah sebagai berikut:

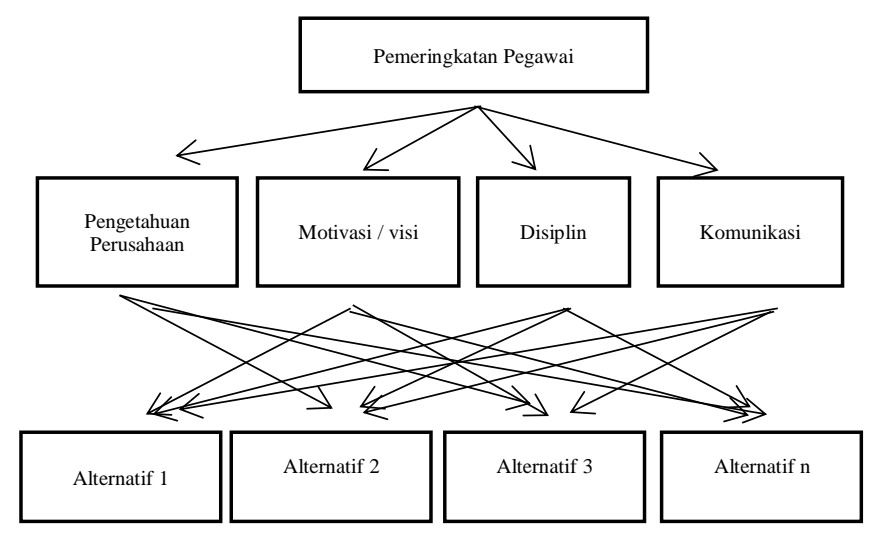

Gambar 3.1 Struktur Penelitian

\subsection{Matriks Perbandingan Berpasangan}

Matriks perbandingan berpasangan dilakukan untuk penilaian perbandingan antara keriteria satu dengan yang lainnya, seperti pengetahuan, motivasi, disiplin dan komunikasi Berikut tabel matriks perbandingan berpasangan pemeringkatan pegawai.

Tabel 3.1 Matriks perbandingan berpasangan

\begin{tabular}{|l|c|c|c|c|}
\hline \multicolumn{1}{|c|}{ Kriteria } & Pengetahuan & Motivasi & Komunikasi & Disiplin \\
\hline Pengetahuan & 1 & 3 & 4 & 5 \\
\hline Motivasi & $1 / 3$ & 1 & 2 & 2 \\
\hline Komunikasi & $1 / 5$ & $1 / 2$ & 1 & 3 \\
\hline Disiplin & $1 / 5$ & $1 / 2$ & $1 / 3$ & 1 \\
\hline
\end{tabular}

\subsection{Menentukan Nilai Eigen}

Langkah pertama untuk menghitung nilai eigen setiap kriteria adalah dengan mengubah matriks kriteria pada tabel 3.1 menjadi bilangan desimal. Berikut tabel matriks kriteria setelah diubah menjadi bilangan desimal. 
Tabel 3.2 Matriks kriteria

\begin{tabular}{|l|c|c|c|c|}
\hline \multicolumn{1}{|c|}{ Kriteria } & Pengetahuan & Motivasi & Komunikasi & Disiplin \\
\hline Pengetahuan & 1 & 3 & 4 & 5 \\
\hline Motivasi & 0,333 & 1 & 2 & 2 \\
\hline Komunikasi & 0,200 & 0,500 & 1 & 3 \\
\hline Disiplin & 0,200 & 0,500 & 0,333 & 1 \\
\hline
\end{tabular}

Selanjutnya menjumlahkan setiap kolom pada masing-masing kriteria. Kriteria pada kolom pengetahuan penjumlahannya sebagai berikut: $1+0,333+0,200+0,200$. Begitupun sama dengan kriteria lainnya sehingga menghasilkan tabel berikut:

Tabel 3.3 Jumlah matriks perbandingan kriteria

\begin{tabular}{|l|c|c|c|c|}
\hline \multicolumn{1}{|c|}{ Kriteria } & Pengetahuan & Motivasi & Komunikasi & Disiplin \\
\hline Pengetahuan & 1 & 3 & 4 & 5 \\
\hline Motivasi & 0,333 & 1 & 2 & 2 \\
\hline Komunikasi & 0,200 & 0,500 & 1 & 3 \\
\hline Disiplin & 0,200 & 0,500 & 0,333 & 1 \\
\hline Jumlah & $\mathbf{1 , 4 3 3}$ & $\mathbf{5}$ & $\mathbf{7 , 3 3 3}$ & $\mathbf{1 1}$ \\
\hline
\end{tabular}

Setelah mendapatkan jumlah pada masing-masing kolom kriteria maka langkah selanjutnya adalah dengan membagi nilai masing-masing kriteria dengan hasil jumlah kolom kriteria. Berikut tabel yang dihasilkan.

Tabel 3.4 Matriks hasil pembagian

\begin{tabular}{|c|c|c|c|c|}
\hline Kriteria & Pengetahuan & Motivasi & Komunikasi & Disiplin \\
\hline Pengetahuan & 0,698 & 0,6 & 0,545 & 0,454 \\
\hline Motivasi & 0,232 & 0,2 & 0,273 & 0,182 \\
\hline Komunikasi & 0,139 & 0,1 & 0,136 & 0,273 \\
\hline Disiplin & 0,139 & 0,1 & 0,045 & 0,091 \\
\hline
\end{tabular}

Perhitungan diatas didapat dari pembagian antara kolom setiap kriteria dengan hasil jumlah setiap kolom. Contoh nilai 0,698 adalah hasil dari pembagian 1 dengan 1,433. Langkah selanjutnya adalah menghitung jumlah baris pada masing-masing kriteria. berikut tabel hasil penjumlahan baris setiap kriteria.

Tabel 3.5 Jumlah kolom Matriks perbandingan

\begin{tabular}{|l|c|c|c|c|c|}
\hline \multicolumn{1}{|c|}{ Kriteria } & Pengetahuan & Motivasi & Komunikasi & Disiplin & Jumlah \\
\hline Pengetahuan & 0,698 & 0,6 & 0,545 & 0,454 & $\mathbf{2 , 2 9 7}$ \\
\hline Motivasi & 0,232 & 0,2 & 0,273 & 0,182 & $\mathbf{0 , 8 8 7}$ \\
\hline Komunikasi & 0,139 & 0,1 & 0,136 & 0,273 & $\mathbf{0 , 6 4 0}$ \\
\hline Disiplin & 0,139 & 0,1 & 0,045 & 0,091 & $\mathbf{0 , 3 7 5}$ \\
\hline
\end{tabular}

Langkah terakhir adalah menghitung nilai eigen pada masing-masing kriteria. nilai eigen didapat dengan cara pembagian jumlah baris dengan banyaknya kriteria $(n=4)$. Berikut tabel hasil eigen pada masingmasing kriteria. 
Tabel 3.6 Nilai Eigen Kriteria

\begin{tabular}{|l|c|}
\hline \multicolumn{1}{|c|}{ Kriteria } & Nilai Eigen \\
\hline Pengetahuan & 0,574 \\
\hline Motivasi & 0,222 \\
\hline Komunikasi & 0,162 \\
\hline Disiplin & 0,094 \\
\hline
\end{tabular}

Hasil dari eigen tersebut merupakan data yang akan dijadikan nilai pembanding pada masingmasing kriteria.

\subsection{Menguji Konsistensi}

Setelah didapatkan nilai eigen maka selanjutnya adalah menguji konsistensi pembobotan pada masing-masing kriteria. pengujian ini berfungsi sebagai validitas data pembobotan yang diberikan untuk setiap kriteria. uji validitas ini berdasarkan tabel indeks Random konsistensi (RI).

\subsection{Menentukan Nilai Eigen Maksimum $\left(\lambda_{\text {maks }}\right)$}

$\lambda_{\text {maks }}$ diperoleh dengan cara menjumlahkan hasil jumlah kolom ke bentuk desimal dengan nilai eigen pada masing-masing kriteria.

$$
\begin{aligned}
\lambda_{\text {maks }} & =(1,433 \times 0,574)+(5 \times 0,222)+(7,333 \times 0,162)+(11 \times 0,094) \\
& =0,823+1,11+1,188+1,034 \\
& =4,155
\end{aligned}
$$

Nilai 4,155 merupakan nilai $\lambda_{\text {maks }}$ yang diperoleh.

\subsection{Menghitung Indeks Konsistensi (CI)}

Rumus untuk mencari CI adalah:

$$
\begin{aligned}
& \mathrm{CI}=(\lambda \text { maks }-\mathrm{n}) /(\mathrm{n}-1) \\
& \mathrm{CI}=(4,155-4) /(4-1) \\
& \mathrm{CI}=0,052
\end{aligned}
$$

Hasil akhir perhitungan CI adalah 0,052.

\subsection{Menghitung Rasio Konsistensi (CR)}

Langkah terakhir dalam pengujian adalah menghitung CR. Jika CR $<0,1$ maka pembobotan pada setiap kriteria dapat dinyatakan konsisten. Rumus menghitung CR adalah sebagai berikut:

$$
\mathrm{CR}=\mathrm{CI} / \mathrm{RI}
$$

RI bernilai 0,90 berdasarkan tabel 3.8 dengan banyaknya kriteria $\mathrm{n}=4$ adalah 0,90 .

$$
\begin{aligned}
& \mathrm{CR}=(0,052) /(0,90) \\
& \mathrm{CR}=0,058
\end{aligned}
$$


Dengan nilai CR adalah 0,058 maka pembobotan pada setiap kriteria dapat dikatakan konsisten karena $\mathrm{CR}<0,1$.

\subsection{Menghitung Nilai Eigen Setiap Hirarki}

Menghitung nilai eigen pada setiap hirarki disini adalah menghitung nilai dari masing-masing kriteria. Nilai hirarki yang telah ditetapkan adalah Sangat Baik, Baik dan Cukup. Berikut pembobotan untuk setiap hirarki.

Tabel 3.7 Tabel matriks hirarki

\begin{tabular}{|l|c|c|c|}
\hline \multicolumn{1}{|c|}{ Kriteria } & Sangat baik & Baik & Cukup \\
\hline Sangat Baik & 1 & 3 & 5 \\
\hline Baik & 0,333 & 1 & 3 \\
\hline Cukup & 0,2 & 0,333 & 1 \\
\hline
\end{tabular}

Sama seperti menghitung nilai eigen kriteria langkah selanjutnya adalah dengan menjumlahkan kolom pada masing-masing hirarki.

Tabel 3.8 Jumlah matriks hirarki

\begin{tabular}{|l|c|c|c|}
\hline \multicolumn{1}{|c|}{ Kriteria } & Sangat baik & Baik & Cukup \\
\hline Sangat Baik & 1 & 3 & 5 \\
\hline Baik & 0,333 & 1 & 3 \\
\hline Cukup & 0,2 & 0,333 & 1 \\
\hline Jumlah & $\mathbf{1 , 5 3 3}$ & $\mathbf{4 , 3 3 3}$ & $\mathbf{9}$ \\
\hline
\end{tabular}

Langkah selanjutnya adalah dengan membagi masing-masing nilai hirarki dengan hasil dari penjumlahan. Berikut hasil yang didapat:

Tabel 3.9 Matriks hirarki hasil pembagian

\begin{tabular}{|l|c|c|c|}
\hline \multicolumn{1}{|c|}{ Kriteria } & Sangat baik & Baik & Cukup \\
\hline Sangat Baik & 0,652 & 0,692 & 0,556 \\
\hline Baik & 0,217 & 0,231 & 0,333 \\
\hline Cukup & 0,130 & 0,077 & 0,111 \\
\hline
\end{tabular}

Hasil dari tabel 3.9 kemudian dijumlahkan setiap barisnya. Sehingga menghasilkan tabel berikut ini:

Tabel 3.10 hasil jumlah matriks hirarki

\begin{tabular}{|l|c|c|c|}
\hline \multicolumn{1}{|c|}{ Kriteria } & Sangat baik & Baik & Cukup \\
\hline Sangat Baik & 0,652 & 0,692 & 0,556 \\
\hline Baik & 0,217 & 0,231 & 0,333 \\
\hline Cukup & 0,130 & 0,077 & 0,111 \\
\hline
\end{tabular}

Selanjutnya adalah menghitung nilai eigen. Nilai eigen didapat dengan cara membagi hasil jumlah baris dengan banyaknya kriteria $(\mathrm{n}=3)$. Maka hasil akhir yang didapatkan adalah sebagai berikut:

Tabel 3.11 Nilai Eigen Hirarki

\begin{tabular}{|l|c|}
\hline \multicolumn{1}{|c|}{ Kriteria } & Nilai Eigen \\
\hline Sangat Baik & 0,574 \\
\hline Baik & 0,222 \\
\hline Cukup & 0,162 \\
\hline
\end{tabular}




\subsection{Menghitung Hasil}

Dari hasil perhitungan sebelumnya maka diperoleh nilai eigen pada tabel 3.6 dan nilai eigen pada skala hirarki pada tabel 3.11 maka langkah selanjutnya adalah dengan cara menguji data pada setiap nilai masing-masing pegawai. Berikut data uji yang telah diterima oleh tim penyeleksi dengan observasi dari tes tulis dan wawancara:

Tabel 3.12 Hasil Tes Tulis dan Wawancara

\begin{tabular}{|c|l|c|c|c|c|}
\hline No & \multicolumn{1}{|c|}{ Nama } & Iptek & Motivasi & Komunikasi & Disiplin \\
\hline 1 & Ari Suryani & 70 & 90 & 90 & 80 \\
\hline 2 & Saropudin & 80 & 70 & 70 & 80 \\
\hline 3 & Lutfhi & 70 & 70 & 75 & 80 \\
\hline 4 & Rendi Firmansyah & 80 & 60 & 70 & 75 \\
\hline 5 & Santi Juliawati & 70 & 70 & 75 & 80 \\
\hline 6 & Ade Zaenal Mutaqin & 65 & 70 & 65 & 70 \\
\hline 7 & Andri & 90 & 90 & 90 & 80 \\
\hline 8 & Taufik & 95 & 85 & 80 & 80 \\
\hline 9 & M Agung P & 90 & 90 & 90 & 85 \\
\hline 10 & Arif Saepul Rohman & 90 & 85 & 70 & 80 \\
\hline 11 & Soni Muhammad Sidik & 80 & 90 & 90 & 85 \\
\hline
\end{tabular}

Ilmu pengetahuan (iptek) didapat melalui tes tulis yang dilakukan terhadap pegawai. Tes iptek ini berupa pengetahuan tentang perusahaan. Tes motivasi dan komunikasi dilakukan melalui proses wawancara terhadap pegawai. Dan yang terakhir kriteria disiplin didapat berdasarkan kehadiran pada saat bekerja.

Langkah selanjutnya adalah mengubah nilai dari setiap kriteria kedalam skala hirarki dengan ketentuan sebagai berikut:

Tabel 3.13 Ketentuan Nilai

\begin{tabular}{|l|c|l|}
\hline \multicolumn{1}{|c|}{ Skala Kriteria } & Nilai & \multicolumn{1}{c|}{ Keterangan } \\
\hline Sangat Baik & $>80$ & Lebih besar dari 80 \\
\hline Baik & $70<$ Baik $\leq 80$ & $\begin{array}{l}\text { Lebih besar dari } 70 \\
\text { dan kurang dari atau } \\
\text { sama dengan } 80\end{array}$ \\
\hline Cukup & $\leq 70$ & Kurang dari 70 \\
\hline
\end{tabular}

Langkah berikutnya adalah mengkonversi tabel 3.12 menggunakan tabel 3.13. Langkah terakhir adalah menghitung masing-masing nilai eigen pegawai dengan cara perkalian nilai eigen vector kriteria dengan vector sub kriteria kemudian hasil dari perkalian tersebut dijumlahkan. Hasil penjumlahan tersebut yang merupakan nilai akhir dari perhitungan. Contoh pegawai dengan nama Ari Suryani. Nilai yang didapat Ari Suryani adalah Iptek $=$ C, Motivasi $=$ SB, Komunikasi $=$ SB dan Disiplin $=$ B. Maka nilai yang didapat Ari Suryani adalah:

Eigen $=($ Nilai eigen $C x$ Nilai eigen Iptek $)+($ Nilai eigen SB $x$ Nilai eigen motivasi $)+($ Nilai eigen SB $\mathrm{x}$ Nilai eigen komunikasi $)+($ Nilai eigen $\mathrm{B}$ x Nilai eigen Disiplin)

Eigen $=(0,106 \times 0,574)+(0,633 \times 0,222)+(0,633 \times 0,162)+(0,260 \times 0,094)$

Eigen $=0,061+0,140+0,102+0,024$

Eigen $=0,327$ 
Maka nilai akhir Ari Suryani adalah 0,327. Begitupun dengan nilai pegawai lainnya. Berikut tabel hasil perhitungan keseluruhan pegawai berprestasi. Berikut ranking calon pegawai berprestasi terurut dari yang terbesar.

Tabel 3.15 Ranking pegawai berprestasi

\begin{tabular}{|c|l|c|c|c|c|c|}
\hline No & \multicolumn{1}{|c|}{ Nama } & Iptek & Motivasi & Komunikasi & Disiplin & Nilai Eigen \\
\hline 1 & M Agung P & 0.363 & 0.141 & 0.103 & 0.06 & 0.666 \\
\hline 2 & Andri & 0.363 & 0.141 & 0.103 & 0.024 & 0.631 \\
\hline 3 & Taufik & 0.363 & 0.141 & 0.042 & 0.024 & 0.57 \\
\hline 4 & Arif S & 0.363 & 0.141 & 0.017 & 0.024 & 0.545 \\
\hline 5 & Soni Muhammad Sidik & 0.149 & 0.141 & 0.103 & 0.06 & 0.452 \\
\hline 6 & Ari Suryani & 0.061 & 0.141 & 0.103 & 0.024 & 0.328 \\
\hline 7 & Saropudin & 0.149 & 0.024 & 0.017 & 0.024 & 0.214 \\
\hline 8 & Rendi Firmansyah & 0.149 & 0.024 & 0.017 & 0.024 & 0.214 \\
\hline 9 & Lutfhi & 0.061 & 0.024 & 0.042 & 0.024 & 0.151 \\
\hline 10 & Santi Juliawati & 0.061 & 0.024 & 0.042 & 0.024 & 0.151 \\
\hline 11 & Ade Zaenal Mutaqin & 0.061 & 0.024 & 0.017 & 0.01 & 0.112 \\
\hline
\end{tabular}

Dari tabel 3.15 dapat dilihat ranking terbesar ke terkecil maka dapat dilihat kandidat yang paling layak sebagai pegawai berprestasi adalah M Agung P disusul oleh Andri, Taufik dan selanjutnya.

\section{Kesimpulan dan Saran}

\subsection{Kesimpulan}

AHP (analytic hierarchy process) merupakan metode pemilihan berdasarkan banyak kriteria. Berdasarkan penelitian ini, AHP membuat ranking pada setiap calon tersebut. Ranking yang paling tinggi didapat oleh M Agung P dengan nilai eigen 0.666 disusul berikutnya Andri dengan nilai 0.631 dan selanjutnya. Berdasarkan data yang ada maka M Agung P merupakan kandidat terkuat menjadi pegawai berprestasi disusul ranking dibawahnya.

\subsection{Saran}

Saran dalam penelitian ini adalah sebagai berikut:

1. Dari penelitian yang telah dilakukan maka disarankan untuk melakukan penelitian menggunakan metode AHP dengan kriteria lebih banyak. Hal ini berfungsi supaya nilai akhir yang didapat sangat bervariasi.

2. Dalam membuat pembobotan diusahakan $\mathrm{CR}=0$ supaya nilai validitasnya $100 \%$.

Diharapkan dilakukan penelitian serupa dengan hirarki kriteria lebih banyak.

\section{Referensi}

[1] Astuti, Yuli, M. Suyanto, and Kusrini Kusrini. AHP Untuk Pemodelan SPK Pemilihan Sekolah Tinggi Komputer. Jurnal Teknologi Informasi Respati. 7.20, 2017.

[2] Arba'i, Jazimatul Husna. Penerapan Soft-skill Bagi Pustakawan Dalam Meningkatkan Mutu Perpustakaan. Akademia. 2012.

[3] Fatih, Defi Rahmah, and Dwi Kurnia Basuki. DSS Untuk Rekomendasi Pemilihan Jurusan Pada Perguruan Tinggi Bagi Siswa SMU. EEPIS Final Project, 2011. 
[4] Meliani, Gina Rahayu, and Andri Suryadi. Game Artificial Intelligent: RAM City Tower Dengan Algoritma A. Jurnal Petik Vol.3 No.2, 2017.

[5] E. Harahap and A. Suryadi. Efektifitas Load Balancing Dalam Mengurangi Kemacetan Jalan Raya. Jurnal Matematika UNISBA. Vol.16 No.2 Desember 2017.

[6] E. Harahap. Analisis Matematika AHP: Pengambilan Keputusan Multi Kriteria Dalam Pemilihan Jenis Komputer Terbaik. Jurnal Matematika UNISBA. Vol.2 No.1, 2003.

[7] E. Harahap. Strategi Perencanaan Instalasi Jaringan Internet Menggunakan Metode Analitic Hierarchy Process (AHP). Jurnal Matematika UNISBA. Vol.3 No.1, 2004.

[8] E. Harahap, W. Sakamoto, and H. Nishi. Failure prediction method for network management system by using Bayesian network and shared database. Information and Telecommunication Technologies (APSITT), 2010 8th Asia-Pacific Symposium on. IEEE, 2010.

[9] Kholis, Azizul. Identifikasi Hardskill dan Softskill Sarjana Akuntansi (Studi Empiris di Kota Medan). Jurnal Mediasi 2.05 (2016): 44-55.

[10] Maharrani, R.H., dkk. Penerapan metode analytical hierarchy Process dalam penerimaan karyawan pada PT. Pasir Besi Indonesia. Jurnal Teknologi Informasi, Volume 6 Nomor 1, April 2010, ISSN 14149999

[11] J. Nuraini, M. Y. Fajar, dan E. Harahap. Pemilihan Campuran Biodiesel Terbaik Berdasarkan Penggabungan Analytic Hierarchy Process (AHP) Dan Technique For Order Preference By Similarity To Ideal Solution (TOPSIS). Jurnal Matematika UNISBA. Vol. 16 No. 1, Mei 2017.

[12] Pare, Selfina. Sistem Pendukung Keputusan Pemilihan Program Studi Pada Perguruan Tinggi. Mustekanimha 2.1 (2013): 58-70.

[13] Saaty, T.L., 2004. Decision Making -The Analytic Hierarchical Process and The Analytic Network Process. Journal of Systems Science and Systems Engineering. Vol 13(1) : 35. 2014.

[14] Setiawan, Alexander, Muhammad Isa Irawan, and Robin Wijaya. Perancangan dan Pembuatan Aplikasi Decision Support System Pada Departemen HRD dan Pembelian dengan Menggunakan Metode Analytical Hierarcy Process (AHP). Semesta Teknika 10.1 (2007): 107-125.

[15] E Harahap, J Wijekoon, R Tennekoon, F Yamaguchi, S Ishida, H Nishi. Modeling of router-based request redirection for content distribution network. International Journal of Computer Applications (IJCA) 76 (13), 2013. pp. 37-46.

[16] Wicaksana, dan I. Wayan Simri. Softskills: Pengertian Softskill. Mediasi (2012): 4-13.

[17] Suryadi, Andri. Sistem Pengambilan Keputusan Untuk Pemilihan Teknisi Lab Dengan Multi Kriteria Menggunakan Metode AHP (Analytic Hierarchy Process). Mosharafa. Vol.5 No.1 2013

[18] Suryadi, Andri, Dian Nurdiana, dan Ilmu Pendidikan Garut. Sistem Pendukung Keputusan Seleksi Ujian Masuk Perguruan Tinggi Menggunakan NBC (Naive Bayes Classifier). Kinetik 1.3 (2016): 173-182.

[19] Turban. Decision Support Systems and Intelligent Systems (Sistem Pendukung Keputusan dan Sistem Cerdas). Jilid 1, Andi Offset, Yogyakarta. 2005. 